University of Montana

ScholarWorks at University of Montana

$12-2000$

\title{
Long-Toed Salamanders in Harvested and Intact Douglas-Fir Forests of Western Montana
}

\author{
George P. Naughton \\ Colin B. Henderson \\ Kerry R. Foresman \\ University of Montana - Missoula, foresman@mso.umt.edu \\ Rex L. McGraw II
}

Follow this and additional works at: https://scholarworks.umt.edu/biosci_pubs

Part of the Biology Commons

Let us know how access to this document benefits you.

\section{Recommended Citation}

Naughton, George P.; Henderson, Colin B.; Foresman, Kerry R.; and McGraw, Rex L. II, "Long-Toed Salamanders in Harvested and Intact Douglas-Fir Forests of Western Montana" (2000). Biological Sciences Faculty Publications. 302.

https://scholarworks.umt.edu/biosci_pubs/302

This Article is brought to you for free and open access by the Biological Sciences at ScholarWorks at University of Montana. It has been accepted for inclusion in Biological Sciences Faculty Publications by an authorized administrator of ScholarWorks at University of Montana. For more information, please contact scholarworks@mso.umt.edu. 


\title{
LONG-TOED SALAMANDERS IN HARVESTED AND INTACT DOUGLAS-FIR FORESTS OF WESTERN MONTANA
}

\author{
George P. Naughton, ${ }^{1,3}$ Colin B. Henderson, ${ }^{2,4}$ Kerry R. Foresman, ${ }^{2}$ and Rex L. McGraw II ${ }^{1,5}$ \\ ${ }^{1}$ Wildlife Biology Program, School of Forestry, The University of Montana, Missoula, Montana 59812 USA \\ ${ }^{2}$ Division of Biological Sciences, The University of Montana, Missoula, Montana 59812 USA
}

\begin{abstract}
There is little known about how timber harvest practices have affected terrestrial amphibians in the northern Rocky Mountains. Especially lacking is information on the effects of revised harvest methods that fall within the framework of environmental or New Forestry. We estimated the relative abundance of a common forest amphibian, the long-toed salamander (Ambystoma macrodactylum) captured in pitfall arrays on intact, environmentally harvested, and overstory-removal harvested sites in mixed-conifer forests of western Montana. Pitfall data from 1994 through 1996 showed that previously logged sites contained significantly fewer long-toed salamanders regardless of harvest method used. The number of salamanders captured on intact sites $\left(3.1\right.$ salamanders $\left.\cdot[\operatorname{array}]^{-1} \cdot[100 \mathrm{~d}]^{-1}\right)$ was nearly three times the number captured on logged sites $\left(1.2\right.$ salamanders $\cdot[\text { array }]^{-1} \cdot[100$ d] $]^{-1}$ ). Habitat conditions measured in conjunction with trapping efforts indicated that lower amphibian abundance was associated with decreased numbers of large live trees. Declines in amphibian abundance occurred in the absence of changes in understory vegetation that typically occur when forest canopy is reduced. Our findings suggest that long-toed salamanders responded to changes in the physical environment, probably increased temperatures and decreased moisture. That salamanders should respond so dramatically indicates that immediate changes in physical conditions may profoundly alter habitat quality even when other components of the habitat are unaffected.
\end{abstract}

Key words: Ambystoma macrodactylum; amphibian; disturbance; environmental forestry; forest management; habitat associations; long-toed salamander; Montana; New Forestry; overstory removal; Rocky Mountains; salamander.

\section{INTRODUCTION}

Despite the importance of amphibians in terrestrial ecosystems (Burton and Likens 1975, Hairston 1987) and their sensitivity to environmental change (Wyman 1990, Blaustein and Olson 1991, Blaustein 1994, Corn 1994, Blaustein et al. 1995), the status of amphibian populations has only recently become a concern of forest management and monitoring programs (Gibbons 1988, Szaro et al. 1988). Many amphibians depend on the temperature, moisture, and cover characteristics provided by undisturbed mature forests (Stiven and Bruce 1988, Welsh 1990, Corn and Bury 1991). Consequently, excessive harvesting of old-growth forests has been suggested as one cause for the broad declines that are occurring in a number of North American amphibians (Walls et al. 1992).

Past logging practices in western forests paid little concern to the broader issues of forest ecosystem sus-

Manuscript received 14 December 1998; revised 1 July 1999; accepted 23 September 1999; final version received 12 November 1999.

${ }^{3}$ Present address: Division of Sport Fish, Alaska Department of Fish and Game, P.O. Box 230, Dillingham, Alaska 99576 USA.

${ }^{4}$ Address correspondence to this author.

${ }^{5}$ Present address: Bureau of Land Management, Roseburg District Office, 777 NW Garden Valley Blvd., Roseburg, Oregon 97470 USA. tainability and conservation of biological diversity. Until recently, preferred harvesting practices promoted nearly complete logging of selected stands, accompanied by the burning of all residual woody debris, including snags and deadfall. Deep scarification of soils typically followed to promote tree seedling establishment and to speed stand regeneration. Recognition of the cumulative harmful effects of forest canopy removal and understory habitat destruction stimulated important research into ecologically sustainable forestry practices (Franklin and Forman 1987, Hansen et al. 1991, Franklin et al. 1997). Implementation of research findings has produced several new approaches to timber harvesting commonly labeled environmental or New Forestry. These revised forestry practices are being implemented throughout the Pacific Northwest and the northern Rocky Mountains. As yet, however, research documenting the effectiveness of these practices in conserving vertebrate communities, especially amphibians, is not generally available.

Although it is less diverse than the herpetofauna in other regions of North America, there is growing concern about the status of the Rocky Mountain herpetofauna and the effects that intensive land management is having on the viability of native amphibians (deMaynadier and Hunter, Jr. 1995). Unfortunately, ecological research on the herpetofauna of the northern Rocky Mountains is limited, with little emphasis on 
forest management practices (e.g., Wishard 1977, Daugherty and Sheldon 1982, Corn 1994).

Of the 13 amphibian species presumed to occur in western Montana, the western long-toed salamander (Ambystoma macrodactylum) is perhaps the most common. Its range includes much of the northern Rocky Mountains and the Pacific Northwest. Adults measure $\sim 9 \mathrm{~cm}$ total length and weigh $\sim 2.5 \mathrm{~g}$. Western longtoed salamanders are a semiaquatic species. Metamorphosed adults are fossorial in terrestrial habitats, sheltering and foraging in burrows, beneath rocks or logs in a variety of habitats from sagebrush to alpine meadows up to elevations of $2700 \mathrm{~m}$ (Anderson 1967, Howard and Wallace 1985, Petranka 1998). Adults return to water to breed as soon as open water appears in ponds and lakes from late February through April. Larvae typically mature within the same season the eggs are laid, but may require two years to mature in highelevation habitats (Howard and Wallace 1985).

In this paper we report on the responses of western long-toed salamanders to forest management practices in mixed conifer forests of western Montana. We present findings on the overall effects of timber harvesting on the abundance of terrestrial populations. We also compare traditional overstory-removal timber harvests to lower-impact New Forestry harvests aimed at conserving biological diversity.

\section{Methods}

\section{Stand selection and treatments}

We conducted our study on U.S. Forest Service, Plum Creek Timber Company, and Montana state lands in the Swan Valley $\left(47^{\circ} 35^{\prime} \mathrm{N}, 114^{\circ} 45^{\prime} \mathrm{W}\right), \sim 100 \mathrm{~km}$ northeast of Missoula, Montana, USA. We chose sites in Douglas-fir (Pseudotsuga menziesii) dominated mixed coniferous forest at $\sim 1200 \mathrm{~m}$ elevation. Historically, lower elevation forests in the Swan Valley often were dominated by pines (Pinus spp.) and western larch (Larix occidentalis), but 50 years of fire suppression has allowed Douglas-fir to become dominant over much of the region (Antos and Habek 1981).

Four sites, referred to hereafter as Gordon Ranch, Bucksnort, Gravel Pit South, and Gravel Pit North, were selected along a $30-\mathrm{km}$ north-south axis. The total area of each site subjected to logging ranged from 7 to 28 ha and the proximity of neighboring sites ranged from 0.25 to $16 \mathrm{~km}$. Similarity of habitat and proximity of treatment plots to intact state, federal, and Plum Creek lands were the principal criteria that guided site selection. Each site was divided into three treatment plots which were designated as either (1) intact (control); (2) overstory removal; or (3) New Forestry. Intact plots were located on state or federal land; harvested plots were on Plum Creek land. Cutting and skidding on harvested sites occurred during the winter of 19921993 when the ground was frozen and had sufficient snow cover to reduce soil disturbance by logging ma-

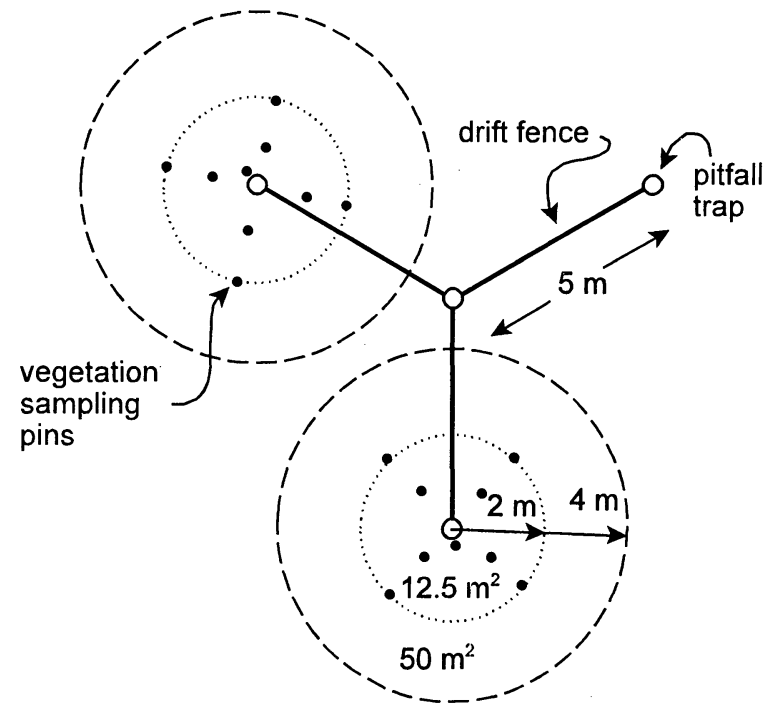

FIG. 1. Design of pitfall arrays used to capture salamanders, together with the sampling scheme used to measure habitat attributes at each array. Array construction used four number-10 cans buried flush to the ground at the center and vertices of a triangle. A 5-m polyethylene sheeting fence 25 $\mathrm{cm}$ high extended from the center to each marginal can. Understory vegetation was sampled using nine pins placed systematically within $2-\mathrm{m}$ radius, $12.5-\mathrm{m}^{2}$ circular plots (dotted circles). Canopy vegetation was measured in larger, 4-m radius, $50-\mathrm{m}^{2}$ circular plots (dashed circles). Two sets of plots were sampled at each array.

chinery (Zasada et al. 1987, Martin 1988, Williams and Buckhouse 1993). Overstory-removal harvests removed all trees $>25 \mathrm{~cm}$ diameter. Logging debris was piled and burned on the periphery of harvested plots. New Forestry harvests were cut according to environmental forestry guidelines implemented by Plum Creek Timber Company. On the New Forestry plots all trees $>25 \mathrm{~cm}$ diameter were removed except for 10-15 dominant or codominant trees per ha. Left trees were selected without respect to species in order to retain preharvest proportions in affected plots. Harvested trees were limbed at felling sites, and branches were scattered. All nonmerchantable trees and snags were retained on both overstory-removal and New Forestry plots.

\section{Salamander sampling}

We constructed three pitfall arrays containing four pitfalls per array on each of the 12 treatment plots in 1994. In 1995, two additional arrays were added per plot. Each array consisted of three, $5 \mathrm{~m}$ long fences made from $15 \mathrm{~cm}$ high plastic sheeting radiating from the center of the array at $120^{\circ}$ angles (Fig. 1). Number10 metal cans set flush with the surface of the ground were placed at the center of each array and at the distal end of each fence. We put small drain holes in the cans to prevent water accumulation. Arrays were placed at least $100 \mathrm{~m}$ apart and more than $100 \mathrm{~m}$ from the edge 
of each plot. The area covered by each array from the center to the outer edge of the distal cans was $86 \mathrm{~m}^{2}$, and the combined area occupied by arrays was $<1 \%$ of the total area of each plot.

Pitfalls were opened from 7 June to 15 August 1994, 28 May to 15 August 1995 , and 29 May to 28 September 1996. Arrays were checked daily; amphibians taken from pitfalls were identified to species and measured (total length). In 1994 captured amphibians were removed $50 \mathrm{~m}$ from the arrays to minimize recaptures. In 1995, all captures were marked for identification by clipping one toe to the middle joint (C. R. Petersen, personal communication) and released immediately adjacent to the array. Because of extremely low recapture frequency $(<2 \%)$, marking was abandoned for 1996.

\section{Habitat attributes}

Habitat information for each array was collected in 1994 using a two-staged design consisting of nested small $\left(12.5 \mathrm{~m}^{2}\right)$ and large $\left(50 \mathrm{~m}^{2}\right)$ circular plots (Fig. 1). At each array, two samples were collected using two randomly selected pitfalls as plot centers. Data from both samples within an array were pooled to provide a single description of the habitat within the immediate vicinity of each array. Within the small plots, nine, $1 \mathrm{~m}$ tall pins were placed in a crossing pattern at $1-\mathrm{m}$ intervals to estimate coverage of understory vegetation classes. All contacts with vegetation were tallied in 1-dm intervals along each pin. Vegetation classes included forb, graminoid, shrub, litter (dead herbaceous and decomposed organic debris), and woody debris (logs and dead branches $>1 \mathrm{~cm}$ diameter). Understory data for $12.5 \mathrm{~m}^{2}$ plots, up to $1 \mathrm{~m}$ height, included mean percentage volume for each vegetation class and mean percentage volume of woody debris and litter. Overstory data collected by species within the $50 \mathrm{~m}^{2}$ plot included number of trees, number of snags, and diameter at breast height for both live and dead trees.

General habitat changes caused by logging were measured on 1-ha subplots located near the center of each experimental plot. Systematic placement of 20 points assured homogeneous sampling within the subplots. At each point, tree and understory sampling followed the same methods described above with one difference. Understory vegetation data were collected from just one $12.5-\mathrm{m}^{2}$ circular quadrat centered on each sampling point within the subplots. Sampling for general habitat changes was conducted yearly from 1992 to 1994 .

\section{Statistical analysis}

We converted the cumulative catch of salamanders on each plot in each year to catch per unit effort (CPUE) of pitfall trapping to estimate the relative abundances of long-toed salamanders:

$$
\text { CPUE }=\frac{C_{i}}{A_{i} T_{i}} \cdot 100
$$

where $C_{i}=$ total number of salamanders captured in the $i$ th sample, $A_{i}=$ the number of arrays in the sample, and $T_{i}=$ number of days effort in the sample. Catches per unit effort were multiplied by 100 to avoid rounding errors during analysis, then were square-root transformed to equalize variances among site and year groups. Levene's statistic calculated for the transformed data did not reject the hypothesis that the transformed data were homoscedastic (Levene $_{\text {sites }}=0.301$, $P=0.824$ Levene $\left._{\text {years }}=0.220, P=0.804\right)$. We used analysis of variance (ANOVA) to test for differences in salamander abundances among harvest treatments and among years. Our experimental design included four different locations (blocks). Each block was divided into three plots (intact, New Forestry, and overstory removal). All plots were trapped for three years (subplots). We analyzed the data as a randomized block design with repeated measures. The $P$ value for significance of all tests was set at 0.05 .

We used multivariate analysis of variance (MANOVA) to test for differences in habitat attributes among sites and treatments. Canonical discriminant function analysis was used with MANOVA to determine the relative importance of habitat attributes in distinguishing among sites and treatments (Johnson and Wichern 1982). We applied square-root transformations to habitat variables as necessary to achieve homoscedasticity among treatment groups prior to analysis. Salamander abundance and habitat analyses were performed using the GLM procedure in SPSS for Windows 7.5 (SPSS Inc. 1997).

\section{RESUlts \\ Logging effects}

At the beginning of the project in 1992 all 12 experimental plots were similar in tree density and species composition. Douglas-fir (Pseudotsuga menziesii) was dominant on all sites. It comprised $40 \%$ of both total density and basal area (Table 1). Other species that were common included, in order of abundance, lodgepole pine (Pinus contorta), western larch (Larix occidentalis), Engelmann spruce (Picea engelmanni), and ponderosa pine (Pinus ponderosa). Most sites showed some evidence of prior limited timber harvest. There were few trees $>60 \mathrm{~cm}$ diameter, and occasional large stumps dispersed through the stands indicated that selective tree harvesting had occurred within the past 50 years. Portions of the Gordon Ranch plots were more intensively harvested but were at rotation age for the most part. It was apparent that the combination of timber harvesting and fire suppression over the past half century promoted the establishment and dominance of $P$. douglasii in the stands (Antos and Habeck 1981, Habeck 1988).

Final log hauling and site cleanup were completed 
TABle 1. Tree densities (no./ha) of principal merchantable species $(>10 \mathrm{~cm} \mathrm{dbh})$, all species $(>10 \mathrm{~cm} \mathrm{dbh})$, and snags $(>20 \mathrm{~cm} \mathrm{dbh})$ before and after harvest on control and harvested plots.

\begin{tabular}{|c|c|c|c|c|c|c|c|c|}
\hline \multirow[b]{3}{*}{$\begin{array}{l}\text { Harvest } \\
\text { type }\end{array}$} & \multirow[b]{3}{*}{ Period } & \multicolumn{7}{|c|}{ Mean number of trees per hectare (1 SD) } \\
\hline & & \multicolumn{4}{|c|}{ Merchantable species } & \multirow[b]{2}{*}{ All species } & \multirow{2}{*}{$\begin{array}{c}\text { Snags } \\
>20 \mathrm{~cm} \\
\text { diameter }\end{array}$} & \multirow[b]{2}{*}{$\begin{array}{c}\text { Basal } \\
\text { area }\left(\mathrm{m}^{2} / \mathrm{ha}\right)\end{array}$} \\
\hline & & $\begin{array}{c}\text { Larix } \\
\text { occidentalis }\end{array}$ & $\begin{array}{c}\text { Picea } \\
\text { engelmanni }\end{array}$ & $\begin{array}{c}\text { Pinus } \\
\text { ponderosa }\end{array}$ & $\begin{array}{c}\text { Pseudotsuga } \\
\text { menziesii }\end{array}$ & & & \\
\hline Intact & & $93(450)$ & $130(77)$ & $3(5)$ & $235(193)$ & $525(84)$ & $40(2)$ & $43(13)$ \\
\hline \multirow{2}{*}{ New Forestry } & preharvest & $60(29)$ & 68 (15) & $23(33)$ & $150(148)$ & 453 (19) & $30(2)$ & $43(7)$ \\
\hline & postharvest & $50(29)$ & $43(21)$ & $3(5)$ & $80(22)$ & $230(24)$ & $10(1)$ & $19(2)$ \\
\hline \multirow{2}{*}{$\begin{array}{r}\text { Overstory } \\
\text { removal }\end{array}$} & preharvest & $100(37)$ & $33(52)$ & $18(24)$ & $182(22)$ & $488(80)$ & 0 & $51(6)$ \\
\hline & postharvest & 43 (19) & 13 (19) & $20(34)$ & $108(22)$ & $240(82)$ & $1(1)$ & $21(8)$ \\
\hline
\end{tabular}

Note: Data were collected from $2050-\mathrm{m}^{2}$ circular quadrats systematically sampled within 1-ha plots in harvest units.

during the first part of the field season in June 1993. New Forestry harvests removed $35 \%$ of the trees from treated stands, while overstory-removal harvests reduced tree density by $43 \%$ (Table 1 ). In addition to the differences in total number of trees harvested, the distribution of size classes harvested was different as illustrated for $P$. douglasii and $L$. occidentalis (Fig. 2). New Forestry harvests retained the general size distribution of trees within affected stands with the exception of L. occidentalis. All L. occidentalis $>30 \mathrm{~cm}$ diameter were harvested on the New Forestry plots. On the overstory-removal plots the size distribution was sharply truncated for all species, leaving only trees $<30 \mathrm{~cm}$ diameter following harvest. Despite the density differences that resulted from the two harvest treat-

New Forestry plots
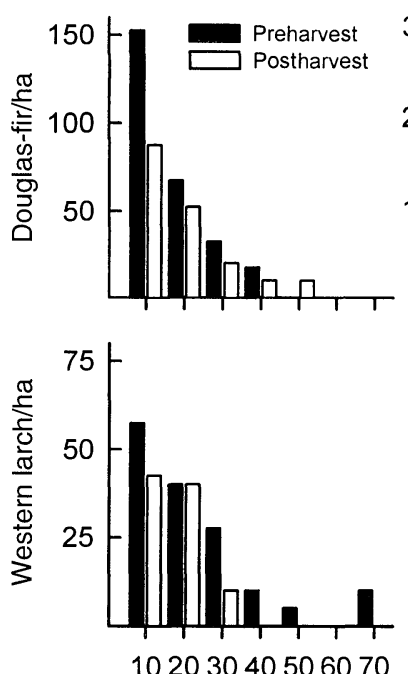

Diameter class $(\mathrm{cm})$

FIG. 2. Size distribution of Douglas-fir (Pseudotsuga menziesii) and western larch (Larix occidentalis) before and after logging on New Forestry and overstory-removal treatment plots. The broader range in tree sizes for $P$. menziesii after logging occurred because some plot boundaries were changed during logging operations, which necessitated establishment of new sampling points in those plots. ments, tree basal area in merchantable size classes on both New Forestry and overstory-removal sites was reduced by $\sim 50 \%$ and became nearly equal between harvest treatments (Table 1). Changes in snag densities on the harvested sites was due to removal of some of the smaller diameter snags, $30 \mathrm{~cm}$ diameter or less. Larger diameter snags were not removed.

Understory vegetation did not show substantial response to the timber harvests (Table 2). Through 1994, we observed no change in the percentage composition of forbs and shrubs on the sites. Woody debris increased slightly immediately after harvest, due to logging activities. The only obvious change in the understory composition that we observed on harvested sites was an increase in grasses, presumably due to increased sunlight, higher temperatures, and drier conditions that resulted from logging. Combined vegetative biomass, indicated by total percentage of volume $1 \mathrm{~m}$ above the ground, remained nearly constant. Dry conditions caused a drop in understory biomass in 1993, but by 1994 when the amphibian study began, understory biomass was at preharvest levels on all plots.

\section{Salamander abundance}

In 1994, we captured 75 salamanders on all arrays (total trapping effort $=2484$ array days). In 1995, we caught 128 salamanders with only two subsequent recaptures (4740 array days). The total catch in 1996 was 121 salamanders (7320 array days). The increase in captures in the second and third years reflects both the increased number of arrays on each plot and longer sampling seasons in 1995 and 1996. The paucity of recaptured animals during 1995 increased our confidence that few, if any, of the animals we captured and displaced in 1994 and 1996 were recaptured later in the season. It also suggests that the population of salamanders was very large, that turnover was high, or both.

Mean CPUE among years was highly variable but declined from 2.9 to 0.5 salamanders. Overall, however, the CPUE on intact plots was nearly three times greater than on harvested plots (Fig. 3). Differences in the relative abundances of salamanders between years were not statistically significantly different $(P>0.10)$, 
TABLE 2. Percentage volume occupied by understory vegetation on intact and harvested plots in the Swan Valley from 1992 through 1994.

\begin{tabular}{lccrr}
\hline & & \multicolumn{2}{c}{ Mean percentage $( \pm 1$ SD) $n=20$} \\
\cline { 3 - 5 } Harvest treatment & Year & \multicolumn{1}{c}{ Forb } & Grass & \multicolumn{1}{c}{ Shrub } \\
\hline Intact & 1992 & $6.9(2.2)$ & $8.5(3.0)$ & $10.5(0.7)$ \\
& 1993 & $5.6(1.7)$ & $7.4(1.7)$ & $9.7(0.4)$ \\
New Forestry & 1994 & $5.0(2.7)$ & $8.3(0.6)$ & $10.8(0.6)$ \\
& 1992 & $5.2(2.9)$ & $11.8(3.8)$ & $10.7(0.5)$ \\
Overstory removal & 1993 & $5.4(0.3)$ & $7.6(2.0)$ & $9.9(0.9)$ \\
& 1994 & $3.2(0.6)$ & $10.6(2.4)$ & $11.1(1.6)$ \\
& 1992 & $3.4(0.7)$ & $12.5(1.4)$ & $10.2(0.2)$ \\
& 1993 & $3.2(0.9)$ & $7.4(1.3)$ & $10.3(0.7)$ \\
& 1994 & $3.1(0.8)$ & $13.3(5.5)$ & $10.9(0.8)$ \\
\hline
\end{tabular}

Notes: Data for 1992 are preharvest conditions. Estimates were made from the number of hits on groups of nine $1-\mathrm{m}$ long pins sampled at 20 points in each of four treatment plots.

but differences in relative abundances among treatments were highly significant $(P<0.01$; Table 3$)$. No interaction between year and harvest type was detectable. Scheffé a posteriori comparisons between treatments indicated that mean CPUE of long-toed salamanders was significantly greater on the control sites than on the New Forestry and overstory-removal sites (Fig. 3). We could not detect any difference in the relative abundance of long-toed salamanders between New Forestry and overstory-removal sites.

\section{Habitat attributes}

Tree and understory analysis yielded measurements on a number of vegetation attributes that we considered important descriptors of salamander habitat quality. In general, harvested sites differed from intact sites in that total basal area of trees and mean basal area per tree were reduced (Table 4). As described earlier, loss of larger older trees was less pronounced on New Forestry plots. Timber removal was associated with slight re-

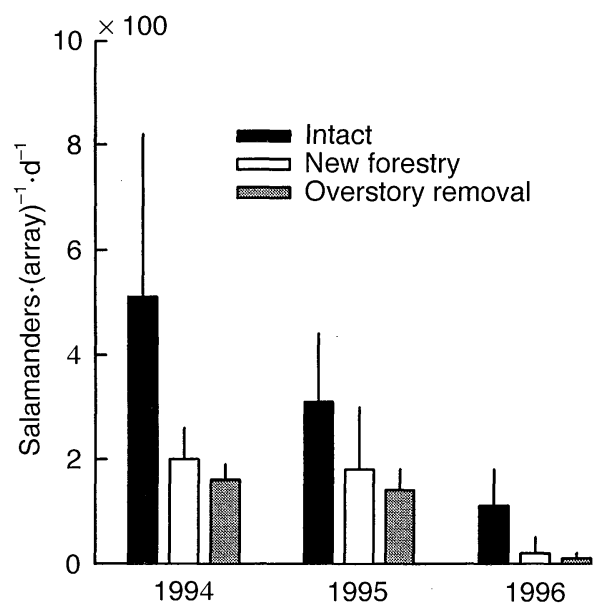

FIG. 3. Western long-toed salamander (Ambystoma macrodactylum) capture rates on intact and logged sites in the Swan Valley of western Montana, USA. Means +1 SD are plotted for four sites per treatment which were resampled each year of the study. Three arrays per plot were sampled in 1994; five arrays per plot were sampled in 1995 and 1996 duction of forbs and a complementary increase in grasses in the understory. The harvested sites also showed increased woody debris as a consequence of logging activities.

Multivariate analysis of variance revealed a significant interaction between site and treatment effects (Table 5). Univariate $F$ tests of group differences suggested that the interaction effect was significant only for mean percentage shrub cover. The Gravel Pit New Forestry South (mean $\pm 1 \mathrm{SD}=3.23 \% \pm 1.46 \%)$, Bucksnort Control $(3.06 \% \pm 1.69 \%)$, Bucksnort Overstory Removal $(2.81 \% \pm 0.12 \%)$ and Gravel Pit New Forestry North $(2.74 \% \pm 0.76 \%)$ plots all had percentage understory shrub cover that was substantially higher than the overall mean $($ mean $=1.95 \% \pm 1.14 \%)$. The absence of a consistent pattern among sites and treatments suggests that the significance of the interaction is attributable to inherent differences in shrub cover that existed on certain plots from the beginning of our study. Also, the lack of concordance between shrub cover and treatment increased our confidence that preexisting habitat conditions did not bias our observations of salamander responses to the different harvests. There were also significant differences in habitat attributes among the three treatments and sites (Table 5). Univariate statistics suggested that mean basal area of trees and mean grass cover were the only attributes that differed among harvest treatments.

Subsequent canonical discriminant function analysis of habitat variables among treatment groups confirmed the relative importance of tree basal area and grass cover in distinguishing among harvest treatments (Table 6). One significant function, based on six variables, resulted and accounted for $\sim 91 \%$ of the among-treatment variance. Standardized canonical coefficients confirmed the MANOVA results. Mean tree basal area and mean grass coverage were the highest weighted variables in the function. Tree basal area obviously was greater postharvest on intact plots; increased grass cover probably indicates a response to increased light that accompanied tree removal on harvested plots. The absence of any other significant changes in habitat struc- 
TABLE 3. Summary of ANOVA for differences in mean numbers of western long-toed salamanders (Ambystoma macrodactylum) captured on intact and harvested forest sites, Swan Valley, Montana.

\begin{tabular}{lrrrrrc}
\hline \multicolumn{1}{c}{ Source } & \multicolumn{1}{c}{ SS } & df & \multicolumn{1}{c}{ MS } & $F$ & $P$ & Power $(\alpha=0.05)$ \\
\hline Site & 6.09 & 3 & 2.03 & & & 0.98 \\
Harvest & 28.17 & 2 & 14.09 & 17.34 & 0.003 & 0.25 \\
Harvest $\times$ site & 4.88 & 6 & 0.81 & & & 0.10 \\
Year(site) & 6.43 & 6 & 1.07 & 1.29 & 0.39 & \\
Harvest $\times$ year & 1.12 & 4 & 0.21 & 0.34 & 0.85 & \\
Residual & 9.93 & 12 & 0.83 & & & \\
\hline
\end{tabular}

Notes: Catch per unit effort (salamanders $\cdot[\text { array }]^{-1} \cdot \mathrm{d}^{-1}$ ) was analyzed. Data were coded by multiplying by 100 and then square-root transformed prior to analysis. A randomized complete block with repeated-measures design was analyzed by the split-plot method using sites as blocks, harvest treatments as main plots, and years as subplots.

ture following harvest indicates that changes in the canopy was the principal correlate with differences in salamander abundance that we observed. The understory vegetation remained mostly unchanged, and differences were not statistically significant (Table 4). Among-site differences identified by canonical discriminant function analysis also confirmed MANOVA findings described above. Once again one function was significant, but accounted for only $\sim 62 \%$ of the amonggroup variance in the data set. Mean shrub and litter cover dominated the function and indicated that, overall, the Bucksnort plots had higher shrub coverage and less litter coverage than the other plots.

\section{Discussion}

One potential weakness in our study is the absence of prelogging estimates of salamander abundance from all plots. It is possible that the differences we observed stem from preexisting differences in salamander populations unrelated to logging. We believe that this is unlikely for two reasons. First, during site selection we matched plots among and within sites as closely as possible to minimize site specific differences that could influence animal populations. Second, the consistency in population trends among all four replicates, which spanned $32 \mathrm{~km}$ between the two most widely separated sites, argues strongly that the logging treatments, rather than site characteristics, produced the salamander responses that we observed.

Long-toed salamanders are the most widespread of all salamanders in Washington, Oregon, Idaho, and western Montana. The variety of habitats in which they occur and the geographic range they occupy (Petranka 1998) suggest tolerance for broad environmental variation. Given their broad ecological amplitude it would be logical to assume that harvested forest stands also fall within the limits of long-toed salamander tolerance. That assumption is supported by observations in several amphibian communities that amphibian abundance was only weakly correlated with old-growth habitat

TABLE 4. Habitat variables measured at intact $(n=12)$, New Forestry $(n=12)$, and overstoryremoval $(n=12)$ pitfall arrays in 1994 .

\begin{tabular}{lccc}
\hline \hline & \multicolumn{3}{c}{ Harvest treatment } \\
\cline { 2 - 4 } Habitat characteristic & Intact & New Forestry & Overstory removal \\
\cline { 2 - 4 } Tree species percentage composition & & \\
$\quad$ Larix occidentalis & $10.0(11.4)$ & $2.7(4.5)$ & $10.0(10.0)$ \\
Pseudotsuga menziesii & $28.6(18.6)$ & $34.5(39.1)$ & $65.0(80.2)$ \\
Picea engelmanni & $27.1(43.6)$ & $2.7(6.4)$ & $3.0(5.4)$ \\
Pinus ponderosa & $1.4(2.9)$ & $5.5(15.5)$ & $1.0(2.7)$ \\
Pinus contorta & $13.6(19.3)$ & $40.9(65.5)$ & $7.0(12.6)$ \\
Abies lasiocarpa & $2.1(3.6)$ & 0 & $5.0(10.8)$ \\
snags & $17.1(13.6)$ & $16.4(24.5)$ & $7.0(9.0)$ \\
Trees per hectare & $2800(1540)$ & $2200(2980)$ & $2000(2220)$ \\
Total basal area $\left(\mathrm{m}^{2}\right)$ per & $108.5(82.6)$ & $27.1(48.0)$ & $20.1(28.0)$ \\
hectare & $228(207)$ & $65(74)$ & $55(51)$ \\
Basal area (cm $\left.{ }^{2}\right)$ per tree & $1.8(1.0)$ & $0.7(0.5)$ & $1.4(1.0)$ \\
Forbs & & & \\
Grasses & $2.7(1.5)$ & $4.3(1.0)$ & $3.9(1.4)$ \\
Shrubs & $2.3(1.2)$ & $2.2(1.4)$ & $2.0(0.8)$ \\
Total live & $6.8(2.4)$ & $7.2(2.3)$ & $7.3(2.0)$ \\
Woody debris & $0.3(0.4)$ & $0.4(0.4)$ & $0.6(0.4)$ \\
Litter & $4.5(1.2)$ & $4.4(1.1)$ & $4.1(0.6)$ \\
\hline Notes: Data are mo &
\end{tabular}

Notes: Data are means, with 1 SD in parentheses. Total basal area is the summed basal area of all trees within a plot averaged across the 12 plots within each treatment. Mean basal area per tree is averaged within plots then across plots. 
TABLE 5. Multivariate analysis of variance for habitat differences at salamander pitfall arrays among treatments and sites.

\begin{tabular}{lcccccc}
\hline \hline \multicolumn{1}{c}{ Source } & Value & $F$ & df & Error df & $P$ & Power $\alpha=0.05$ \\
\hline Site & 0.24 & 2.01 & 18 & 54.23 & 0.03 & 0.92 \\
Treatment & 0.21 & 3.72 & 12 & 38.00 & 0.00 & 0.99 \\
Site $\times$ treatment & 0.11 & 1.56 & 36 & 86.20 & 0.05 & 0.86 \\
\hline
\end{tabular}

structure (Corn and Bury 1991) or even increased in clearcuts and regeneration stands (Harris 1984). The absence of correlation between old-growth characteristics and amphibian abundance led Corn and Bury (1991) to conclude that important microhabitat conditions for amphibians may be supplied by young as well as intact forests.

Other research suggests, however, that amphibians have specialized microclimate and habitat requirements, and that physical and biotic conditions found in different aged forests limit the distribution and abundance of forest amphibians (Welsh 1990). Surveys conducted in the Pacific Northwest have documented declines in amphibian abundance in second-growth managed stands, especially where significant understory habitat disturbance has occurred (Bury 1983, Welsh and Lind 1988, Dupuis et al. 1995). In contrast to Bury (1983) and Dupuis et al. (1995), we did not detect any significant changes in the understory vegetation after logging. In fact, logging was conducted in a manner intended to minimize understory disturbance. Nevertheless, we documented a $70 \%$ reduction in long-toed salamander abundance on the newly harvested New Forestry and overstory-removal stands in 1994 and 1995.

We found that the loss of an intact overstory, reflected in decreased abundance and mean basal area per tree of dominant species, was the critical factor associated with decreased abundance of long-toed salamanders. Amphibians have a low tolerance for hot, dry conditions. Removal of the canopy resulted in a mean $1.8^{\circ} \mathrm{C}$ increase in daily summer temperatures (intact mean $=8.4^{\circ} \mathrm{C}$, New Forestry mean $=10.2^{\circ} \mathrm{C}$, overstory-removal mean $=10.2^{\circ} \mathrm{C}$; McGraw 1997) on harvested sites that probably increased moisture stress on long-toed salamanders (Dupuis et al. 1995). Harris (1984) summarized findings that older, taller, and more structurally complex forests have more daily and seasonal microclimatic stability than younger forests. Dupuis et al. (1995) found soils of young and mature postharvest stands were less moist than those of old growth. High ambient air temperatures, low soil moisture, and wind have been shown to cause dehydration (Hutchinson 1961, Heatwole 1962a, Petranka et al.

TABLE 6. Summary of discriminant analysis for habitat differences among sites and harvest treatments.

\begin{tabular}{|c|c|c|c|c|c|}
\hline \multirow[b]{2}{*}{ Statistic } & \multicolumn{2}{|c|}{ Treatment } & \multicolumn{3}{|c|}{ Site } \\
\hline & Function 1 & Function 2 & Function 1 & Function 2 & Function 3 \\
\hline \multicolumn{6}{|c|}{ Standardized discriminant function coefficients } \\
\hline Mean forb & 0.43 & 0.80 & 0.64 & 0.25 & -0.42 \\
\hline Mean grass & -0.67 & -0.26 & -0.16 & 1.35 & 0.03 \\
\hline Mean litter & 0.06 & -0.49 & -1.10 & 0.42 & -0.32 \\
\hline Mean shrub & 0.39 & 0.49 & 1.16 & -0.77 & 0.89 \\
\hline Mean wood & -0.46 & 0.54 & -0.15 & 0.22 & 0.57 \\
\hline Mean basal area & 0.78 & -0.21 & -0.20 & 0.37 & 0.35 \\
\hline \multicolumn{6}{|l|}{ Mean discriminant scores } \\
\hline Intact & 1.43 & -0.04 & & & \\
\hline New Forestry & -0.81 & -0.43 & & & \\
\hline Overstory removal & -0.63 & 0.47 & & & \\
\hline Gordon Ranch & & & -1.02 & 0.54 & -0.28 \\
\hline Bucksnort & & & 0.52 & 0.43 & 0.51 \\
\hline Gravel Pit S. & & & -0.61 & -0.81 & 0.17 \\
\hline Gravel Pit N. & & & 1.11 & -0.16 & -0.40 \\
\hline \multicolumn{6}{|l|}{ Function summary } \\
\hline Eigenvalue & 1.56 & 0.15 & 0.81 & 0.37 & 0.13 \\
\hline $\begin{array}{l}\text { Percentage discriminating } \\
\text { variance }\end{array}$ & 91.20 & 8.80 & 61.80 & 27.90 & 10.30 \\
\hline Canonical correlation & 0.78 & 0.36 & 0.67 & 0.52 & 0.34 \\
\hline  & 0.00 & 0.51 & 0.03 & 0.22 & 0.44 \\
\hline
\end{tabular}

Notes: Extraction of discriminant functions was performed after multivariate analysis of variance indicated significant $(P<0.05)$ habitat differences among sites and treatments. Stepwise selection of variables was performed based on Mahalanobis distance and was followed by varimax rotation of the pattern matrix (coefficients). 
1993). Thus, the harvested sites may have become less suitable for the long-toed salamanders. The reduction in canopy cover may also have indirectly affected the distribution of long-toed salamanders by changing the temperature and moisture of cover objects (Heatwole $1962 b$; Pough et al. 1987). Exposed logs may be 3.5$5 \times$ warmer than shaded ones (Heatwole 1962b).

Our observations lead us to conclude that microclimate protection under New Forestry cuts was not sufficient to safeguard long-toed salamander populations on affected sites. That may be partly a consequence of the similarity in canopy retention between New Forestry and overstory-removal sites. Recall that, although a proportion of all size classes were retained after New Forestry cuts, the mean basal area of remaining trees on overstory-removal and New Forestry sites were not very different. Nearly equivalent opening of the canopy under both harvest methods would be expected to produce similar responses if canopy closure influences habitat suitability for long-toed salamanders. Added to that, the care that was taken to protect understory microhabitats in both methods minimized differences between them. On both New Forestry and overstory-removal sites, winter logging and retention of snags and coarse woody debris protected vegetation and conserved understory habitat structure. Despite these efforts to conserve understory habitats, long-toed salamander numbers declined on harvested sites. It appears that only by conserving substantially more of the canopy can tolerable microclimates be retained. We think this is unlikely to occur, given the current economic realities of timber management on private and public lands.

What then can be done to promote conservation of long-toed salamanders and other amphibians that inhabit Rocky Mountain forests? Stand replacing disturbance, most often fire, was common in naturally regulated forests in western Montana (Arno 1980, Antos and Habeck 1981). Amphibians, like other terrestrial species adapted to periodic disturbance, either retreated to intact habitats or repopulated disturbed habitats from unaffected neighboring habitats. The disturbance created by both timber harvesting methods in our study was much less severe than that caused by stand replacing fire, and it is probable that many long-toed salamanders in the affected habitats retreated into adjacent unharvested stands. That makes the relative area of harvested and intact forest, the continuity between unharvested patches, and their connections to breeding sites critical to continued persistence of long-toed salamanders in managed forests. To that end we see the emergence of sound landscape management philosophies as vital to conservation of amphibian diversity in Western forests.

\section{ACKNOWLEDGMENTS}

Support for our research was provided by grants from the McIntire-Stennis Cooperative Forestry Research Program, administered by the School of Forestry at The University of
Montana (Grant \# G3216104) and Plum Creek Timber Company. Flathead National Forest, USDA Forest Service, Region 1 generously provided housing for our field crews. We are indebted to Morris Meyerowitz, Jody Smith, and Dustin Henderson, without whose able assistance this work could not have been completed.

\section{Literature Cited}

Anderson, J. D. 1967. A comparison of the life histories of coastal and montane populations of Ambystoma macrodactylum in California. American Midland Naturalist 77:323355.

Antos, J. A., and J. R. Habeck. 1981. Successional development in Abies grandis (Dougl.) Forbes forests in the Swan Valley, western Montana. Northwest Science 55:2639.

Arno, S. F. 1980. Forest fire history in the northern Rockies. Journal of Forestry 78:460-465.

Blaustein, A. R. 1994. Chicken little or Nero's fiddle? A perspective on declining amphibian populations. Herpetologica 50:85-97.

Blaustein, A. R., J. M. Kiesecker, D. G. Hokit, and S. C. Walls. 1995. Amphibian declines and UV radiation. Bioscience 45:514-515.

Blaustein, A. R., and D. H. Olson. 1991. Declining amphibians. Science 253:1467.

Burton, T. M., and G. E. Likens. 1975. Salamander populations and biomass in the Hubbard Brook Experimental Forest, New Hampshire. Copeia 1975:541-546.

Bury, R. B. 1983. Differences in amphibian populations in logged and old-growth redwood forest. Northwest Science 57: $167-178$.

Corn, P. S. 1994. What we know and don't know about amphibian declines in the West. Pages 55-67 in W. W. Covington and L. F. De Bano, technical coordinators. Sustainable ecological systems: implementing an ecological approach to land management. USDA Forest Service, Rocky Mountain Forest and Range Experiment Station, General Technical Report RM-247.

Corn, P. S., and R. B. Bury. 1991. Terrestrial amphibian communities in the Oregon Coast Range. Pages 305-317 in L. F. Ruggiero, K. B. Aubry, A. B. Carey and M. H. Huff, technical coordinators, Wildlife and vegetation of unmanaged Douglas-fir forests. USDA Forest Service, Pacific Northwest Research Station, General Technical Report PNW-GTR-285.

Daugherty, C. H., and A. L. Sheldon. 1982. Age determination, growth, and life-history of a Montana population of the tailed-frog (Ascaphus truei). Herpetologica 38:468474.

deMaynadier, P. G., and M. L. Hunter, Jr. 1995. The relationship between forest management and amphibian ecology: a review of the North American literature. Environmental Review 3:230-261.

Dupuis, L. A., J. N. M. Smith, and F. Bunnell. 1995. Relation of terrestrial-breeding amphibian abundance to tree-stand age. Conservation Biology: 9:645-653.

Franklin, J. F., D. R. Berg, D. A. Thornburgh, and J. C. Tappeiner. 1997. Alternative silvicultural approaches to timber harvesting: variable retention harvest systems. Pages 111-139 in K. A. Kohm, and J. F. Franklin, editors. Creating a forestry for the 21 st Century: the science of ecosystem management. Island Press, Washington, D.C., USA.

Franklin, J. F., and R. T. T. Forman. 1987. Creating landscape patterns by forest cutting: ecological consequences and principles. Landscape Ecology 1:5-18.

Gibbons, J. W. 1988. The management of amphibians, reptiles, and small mammals in North America: the need for an environmental attitude adjustment. Pages 4-10 in R. C. Szaro, K. E. Severson, and D. R. Patton, technical coor- 
dinators. Management of amphibians, reptiles, and small mammals in North America. USDA Forest Service, Rocky Mountain Forest and Range Experiment Station, General Technical Report RM-166. USDA Forest Service, Rocky Mountain Forest and Range Experiment Station, Fort Collins, Colorado, USA.

Habeck, J. R. 1988. Old-growth forests in the Northern Rocky Mountains. Natural Areas Journal 8:202-211.

Hairston, N. G., Sr. 1987. Community ecology and salamander guilds. Cambridge University Press, New York, New York, USA.

Hansen, A. J., T. A. Spies, F. J. Swanson, and J. L. Ohman. 1991. Conserving biodiversity in managed forests: lessons from natural forests. BioScience 41:382-392.

Harris, L. D. 1984. The fragmented forest. Island biogeography theory and the preservation of biotic diversity. University of Chicago Press, Chicago, Illinois, USA.

Heatwole, H. 1962a. Relation of substrate moisture to absorption and water loss by the salamander Plethodon cinereus. Ecology 42:814-819.

Heatwole, H 1962 b. Environmental factors influencing local distribution and activity of the salamander Plethodon $\mathrm{ci}^{-}$ nereus. Ecology 43:460-472.

Howard, J. H., and R. L. Wallace. 1985. Life history characteristics of the long-toed salamander (Ambystoma macrodactylum) from different altitudes. American Midland Naturalist 113:361-373.

Hutchinson, V. H. 1961. Critical thermal maxima in salamanders. Physiological Zoology 34:92-125.

Johnson, R. A., and D. W. Wichern. 1982. Applied multivariate statistical analysis. Prentice Hall, Englewood Cliffs, New Jersey, USA.

Martin, C. W. 1988. Soil disturbance by logging in New England-review and management recommendations. Northern Journal of Applied Forestry 5:30-34.

McGraw, Rex L., II. 1997. Timber harvest effects on metamorphosed and larval long-toed salamanders (Ambystoma macrodactylum). Thesis. The University of Montana, Missoula, Montana, USA.

Petranka, J. W. 1998. Salamanders of the United States and Canada. Smithsonian Institution Press, Washington, D.C., USA.

Petranka, J. W., M. E. Eldridge, and K. E. Haley. 1993. Effects of timber harvesting on southern Appalachian salamanders. Conservation Biology 7:363-370.
Pough, H. F., E. M. Smith, D. H. Rhodes, and A. Collazo 1987. The abundance of salamanders in forest stands with different histories of disturbance. Forest Ecology and Management 20:1-9.

SPSS, Inc. 1997. SPSS for Windows, release 7.5. SPSS, Inc., Chicago, Illinois, USA.

Stiven, A. E., and R. C. Bruce. 1988. Ecological genetics of the salamander (Desmognathus quadramaculatus) from disturbed watersheds in the Southern Appalachian Biosphere Reserve Cluster. Conservation Biology 2:194-205.

Szaro, R. C., K. E. Severson, and D. R. Patton, technical coordnators. 1988. Management of amphibians, reptiles, and small mammals in North America. USDA Forest Service, Rocky Mountain Forest and Range Experiment Station, General Technical Report RM-166. USDA Forest Service, Rocky Mountain Forest and Range Experiment Station, Fort Collins, Colorado, USA.

Walls, S. C., A. R. Blaustein, and J. J. Beatty. 1992. Amphibian biodiversity of the Pacific Northwest with special reference to old-growth stands. Northwest Environmental Journal 8:53-69.

Welsh, H. H., Jr. 1990. Relictual amphibians and old-growth forests. Conservation Biology 4:309-319.

Welsh, H. H. Jr., and A. J. Lind. 1988. Old-growth forests and the distribution of terrestrial herpetofauna. Pages 439458 in R. C. Szaro, K. E. Sieverson, and D. R. Patton, technical coordnators. Management of amphibians, reptiles, and small mammals in North America. USDA Forest Service, Rocky Mountain Forest and Range Experiment Station, General Technical Report RM-166. USDA Forest Service, Rocky Mountain Forest and Range Experiment Station, Fort Collins, Colorado, USA

Williams, J. D., and J. C. Buckhouse. 1993. Winter logging and erosion in a ponderosa pine forest in northeastern Oregon. Western Journal of Applied Forestry 8:19-23.

Wishard, L. N. 1977. Larval growth in (Rana pretiosa): ecological and genetic factors. Thesis. University of Montana, Missoula, Montana, USA

Wyman, R. L. 1990. What's happening to the amphibians? Conservation Biology 4:350-352.

Zasada, J. C., C. W. Slaughter, C. E. Teutsch, J. D. Argyle, and W. Hill. 1987. Winter logging on the Tanana River Flood plain in interior Alaska. Northern Journal of Applied Forestry 4:11-16. 